\title{
Service Quality of the Governments-Physical And Online Perspectives
}

\author{
Tsung-Ju Yang
}

Institute of Service Industries and Management, Minghsin University of Science and Technology, Hsinchu, Taiwan

\begin{abstract}
The governments provide both physical and online service for the citizens. How to improve the citizens' evaluations and behavioural intentions are important issues for government officials. However, previous studies about the both physical and online service quality are still rare. The purposes of the study are to explore the relationships among service quality, citizen satisfaction and word-of-mouth in the both physical and online government services. The researchers survey the citizens in Taiwan and apply regression analysis method to analyse the samples data. The empirical results are as following: First, the results confirm that physical government service quality positively impacts on both citizens' satisfaction and word-of-mouth, and citizens' satisfaction positively impacts on citizens' word-of-mouth. Improving the dimensions of physical government service quality, such as service outcome, environment and interaction services, would increase the citizens' satisfaction and word-of-mouth. Second, the results also confirm that egovernment service quality positively impacts on both citizens' e-satisfaction and e-word-ofmouth, and citizens' e-satisfaction positively impacts on citizens' e-word-of-mouth. Improving the dimensions of online government service quality, such as efficiency, trust reliability and citizen support, would increase the citizens' e-satisfaction and e-word-of-mouth. The researchers compare the physical government services with online government services, the empirical results show the similar effects. Improving service quality of both physical and online services positively impact on both citizens' satisfaction and word-of-mouth. The results provide the government officials implications how to improve the both services qualities of physical and online will increase the citizens' satisfaction and word-of-mouth.
\end{abstract}

Keywords: Physical Government Services, Online Government Services, Service Quality, Citizen satisfaction, Word-of-Mouth 


\section{Introduction}

In the age of information technology, the governments provide both physical and online services for the citizens. It is an important issue for governments to provide high quality services to earn the citizens' positive evaluations and behavioural intentions, such as word-of-mouth. However, most of the public-sector organizations have little progress in customer-friendly (Ha and Lee, 2010). The public sectors should communicate the functions of the e-services and reduce misuse or mismanagement of personal data (Connolly, Bannister and Kearney, 2010). Government webs provide citizens with government information via effective classification, however, service quality and citizens' satisfaction with E-government has been explored rarely (Chung, Sheu and Chien, 2007). Rehman, Kamal and Esichaikul (2016) investigate two user groups, i.e., online and offline, to knowing the citizens' intention to utilize e-government services at different levels of service maturity, i.e., information and transaction levels. Despite the importance of the both physical and online services, the previous studies about the comparison between the physical and online services are still rare. The purposes of the study are to explore the service relationships between physical and online government services.

\subsection{Service quality, Satisfaction and Word-of-Mouth of the Physical Government Services}

Based on the on-site survey, Bai, Lai, Chen, and Hutchinson (2008) confirm that the perceived service quality of public utility services has a multi-dimensional structure with three dimensions: outcome, environment and interaction. The public-sector organizations - health care organizations, local government, police, emergency services, government agencies - have come to realize that customer service and quality are critical issues, however, the public-sector organizations face the difficulties in measuring service quality (Wisniewski and Donnelly, 1996). Chen, Yu and Chang (2005) investigate the customer-oriented service activities in the Taiwanese public sectors and find that performance gaps among the customer-oriented service system are significant. Folz (2004) measure service quality for municipal solid waste recycling programs and shows that service quality of municipal services can advance decision making about what citizens expect and will support in terms of input service quality. Rhee and Rha (2009) identified four main qualities of public service: process quality, outcome quality, design quality, and relationship quality, however, final customers (beneficiaries) give priority to the process and outcome qualities, whereas intermediary customers (social workers) give priority to the design and relationship qualities, and the results show that the critical service quality attributes for satisfaction differ from the types of customers in the public sectors.

Stock (2011) conducted goods and services studies to confirm the inverted U-shaped relationship between the innovativeness of the goods and customer satisfaction. Social and special treatment benefits impact on technical and functional quality and only confidence benefits impact on relationship quality, furthermore, functional and relationship quality impact on the word-ofmouth behaviors. (Ng, David, and Dagger, 2011). Ng, David, and Dagger (2011) highlight the important role of relationship benefits in driving customer perceptions of technical, functional and relationship quality. The importance of service attributes is positively related to service satisfaction (Wen and Chen, 2007), Wen and Chen (2007) explore the factors of service quality of local administrative organizations in Taiwan such as service attitude, politeness, affairs completed on time, staff personal information confidential, staff behavior and morality, convenience of operation 
process application, professional capability of staff, efficiency of inter-department integration, real time service provided by staff, emphasis on public opinion, practical carry out a task by deputy, assistance on the application of urgent cases, etc. Van Ryzin, Muzzio, Immerwahr, Gulick and Martinez (2004) adopts the American Customer Satisfaction Index (ACSI) model to examine the government services and find that perceived quality of government services are the most import factors of satisfaction, then overall satisfaction drives both trust in government officials and intentions to move out of the city. Thus, the researchers propose the hypothesis as follows:

H1a: Physical government service quality positively impacts on citizens' satisfaction.

H2a: Physical government service quality positively impacts on citizens' word-of-mouth.

H3a: Citizens' satisfaction positively impacts on citizens' word-of-mouth.

H4a: Citizens' satisfaction mediates the relationship between physical government service quality and citizens' word-of-mouth.

\section{2 e-Service quality, e-satisfaction and e-Word-of-Mouth of the Online Government Services}

Electronic government is recognized as a means for transforming public governance (Teo, Srivastava and Jiang, 2008). Ha and Lee (2010) identify key processes and builds customer retention and maturity strategies are: obtaining high-quality reliable panel data from the public sector; saving money and time to collect questionnaires; improving customer processes based on surveys; and enhancing service quality. Up to the present, we were unable to identify a service quality evaluation model particularly focused on local online e-Government (Sa, Rocha and Cota, 2016). Sa, Rocha and Cota (2016) focus on three services qualities: traditional, electronic and eGovernment and argue that local e-Government online services should be analyzed and accounted for to improve the services and increase recipients' satisfaction. Janita and Miranda (2018) show the government must have considered to measure the quality of electronic services, such as quality of information, technical efficiency, privacy and communication with the employee.

Citizens had different expectations for the e-government services in Thailand and Indonesia (Mirchandani, Johnson and Joshi, 2008), Mirchandani, Johnson and Joshi (2008) claim that only two relationships were equivalent: first, the financial transactions services positively related to the website efficiency; second, the local information services positively related to the citizen identification with the site. Knowing how citizens to perceive and evaluate online is important to deliver superior service quality (Papadomichelaki and Mentzas, 2012). Papadomichelaki and Mentzas (2012) develop an e-government service quality model (e-GovQual) and a multiple-item scale to measure service quality of governmental sites. Information accuracy, real-time information, accessibility of requested information, and complete online application are the most important functions of government websites (Liang, Lu and Kuo, 2014). New information and communication technologies (ICT) offer the government new possibilities for providing citizens and businesses with better and more efficient services (Verdegem and Verleye, 2009). Chang, Yu and Hung (2010) analyze the case of E-Govern in Taiwan and find the three most important common interests are: helping public administrators manage resources effectively, creating profit and value, and integrating government data vertically. Beldad, van der Geest, de Jong and Steehouder (2012) investigated government Internet users' trust in Dutch and confirm that the 
quality of the online government transaction experience and organizational reputation both can increase citizens' trust in government organizations. Chung, Sheu and Chien (2007) indicated adequate fit of the model as follows: E-Government service quality - service value - users' satisfaction - behavioral intention. The results show that E-Government service quality will positively impacts on users' satisfaction and behavioral intentions.

Connolly, Bannister and Kearney (2010) examine the online service quality of Irish tax filing and collection system, Revenue Online Service (ROS) and show that efficiency and ease of completion influence ROS users' perceptions of value and convenience as well as intentions to use and recommend to peers. Hu, Brown, Thong, Chan, and Tam (2009) examines the determinants of service quality and continuance intention of online services and test citizens' continuance intention of eTax and the results showed that both service characteristics (i.e., security and convenience) and one of the technology characteristics (i.e., usefulness, but not ease of use) are the key of service quality; besides, service quality is the strongest predictor of continuance intention, not perceived usefulness. Hu, Brown, Thong, Chan, and Tam (2009) found that assurance and reliability are the only significant predictors of continuance intention. $\mathrm{Ku}$ and $\mathrm{Chen}$ (2015) investigate the impacts of design and service quality of the website of the public sectors on tourists' satisfaction and continued usage intention and show that the excellence mission and quick navigation in travel services are important to attract travelers. Using Kano's model to study the service quality of government websites, Liang, Lu and Kuo (2014) discover that the government websites users take accessibility as a one-dimensional quality, 18 website attributes such as online applications and inquiries into application progress as attractive quality, four attributes such as privacy protection and information security as must-be quality, and seven attributes such as interaction with public sectors as indifferent quality.

Rana, Dwivedi, Williams and Weerakkody (2015) examine the online public grievance redressal system in India and confirm all the relationships between system quality, information quality, service quality, perceived usefulness, perceived ease of use, perceived satisfaction, perceived risk, and behavioral intention. Electronic government could shape public administrations to be more customer oriented and customer orientation shows effects on the availability of usability on the websites and topics selection (Schedler and Summermatter, 2007). Teo, Srivastava and Jiang (2008) examines the role of trust in e-government success and the results show that trust in government, but not trust in technology, is positively related to trust in egovernment websites, besides, the quality constructs have different effects on "intention to continue" and "satisfaction" with the websites. Veeramootoo, Nunkoo and Dwivedi (2018) claim that citizens' continued usage intention of e-filing is influenced by system quality, user satisfaction and habit, and the users' satisfaction had the strongest impact on the users' continued usage intention. Venkatesh, Thong, Chan and $\mathrm{Hu}$ (2016) confirm that the information quality and channel characteristics impact on citizens' intentions to use e-government, and transparency and trust mediate and moderate the effects of information quality and channel characteristics on intentions. Verdegem and Verleye (2009) argue that user satisfaction may influence on the adoption and use of E-Government services. Thus, the researchers propose the hypothesis as follows:

H1b: e-government service quality positively impacts on citizens' e-satisfaction.

H2b: e-government service quality positively impacts on citizens' e-word-of- mouth. 
$9^{\text {th }}$ INTERNATIONAL CONFERENCE ON MANAGEMENT , ECONOMICS AND HUMANITIES

\author{
26-28 July, 2019 \\ London, United Kingdom
}

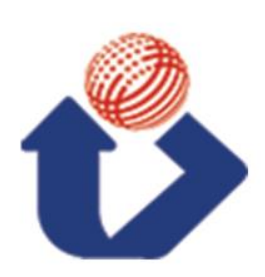

H3b: Citizens' satisfaction of the e-government positively impacts on citizens' e-word-of- mouth. H4b: Citizens' e-satisfaction mediates the relationship between e-government service quality and citizens' e-word-of- mouth.

\title{
Methods
}

\subsection{Sample procedures}

The study surveyed the people perceptions of the government services in Taiwan, including physical and online services. The samples are the people who had received or used both physical and online services from the government in last month. These samples have a good memory to answer the measurements in the study. The study used convenience sampling method and a selfreport questionnaire to collect the samples data. The researchers distributed 300 questionnaires and collected 185 effective samples.

\subsection{Measures Design}

The researcher modified the previous studies to design the measurements of the study. Except the personal data of the samples, such as gender and age, all measurements are used 7-point Likert scale from 1(=strongly disagree) to 7(=strongly agree). The scales of the government service quality are modified the scales proposed by Bai, Lai, Chen and Hutchinson (2008). The measurements are including three dimensions, and service outcome, environment and interaction services are measured by 4,6 and 12 items. The definition of the government service quality is the citizens perceived performance level of the physical government services. The scales of the citizens' satisfaction are modified the scales proposed by Sirdeshmukh, Singh \& Sabol (2002). The scales of the citizens' satisfaction are single dimension, including 3 items. The definition of citizens' satisfaction is the citizens' overall evaluation of the government services. The scales of the citizens' word-of-mouth are single dimension and modified from the scales proposed by $\mathrm{Ng}$, David and Dagger (2011). The scales of the citizens' word-of-mouth are single dimension and including 3 items. The definition of citizens' word-of-mouth is the citizens' recommending the government intention to the others.

The scales of the e-government service quality are modified the scales proposed by Papadomichelaki and Mentzas (2012). The measurements are including four dimensions, and efficiency, trust, reliability and citizen support are measured by 7, 4, 6 and 4 items. The definition of the e-government service quality is the citizens perceived performance level of the online government services. The scales of the citizens' satisfaction of the e-government are modified the scales proposed by Sirdeshmukh, Singh \& Sabol (2002). The scales of the citizens' satisfaction of the e-government are single dimension, including 3 items. The definition of citizens' satisfaction is the citizens' overall evaluation of the e-government services. The scales of the citizens' wordof-mouth of the e-government are single dimension and modified from the scales proposed by $\mathrm{Ng}$, David and Dagger (2011). The scales of the citizens' word-of-mouth are single dimension and including 3 items. The definition of citizens' word-of-mouth of the e-government is the citizens' recommending the e-government intention to the others. 


\section{Results}

\section{Descriptive Statistics}

The study uses the convenience sampling method to collect the user who had both physical and online government services experiences. All sample are volunteers to fill out the questionnaires. The researchers distributed 300 questionnaires and collect 185 valid questionnaires and the valid response rate is $61.7 \%$. The characteristics of samples are: there are 84 males $(45.4 \%)$ and 101 females $(54.6 \%)$ samples. The ages of samples are: $51(27.6 \%)$ are under 30 years old, $46(24.9 \%)$ are between 31 40 years old, 52(28.1\%) are between $41 \sim 50$ years old and 36(19.5\%) are 51 years old above. The education levels of samples are: 51(27.6\%) are under or high school, 46(24.9\%) are college, and $88(47.6 \%)$ are university or above. The occupations of samples are: $48(25.9 \%)$ are service industries, 29(15.7\%) are industrial industries, 37(20\%) are public sectors or school, $29(15.7 \%)$ are housewife/ househusband, and 42(22.7\%) are others.

\section{Reliability and Validity}

The study applies the SPSS statistics software to analyze the samples. The mean, standard deviation and correlation matrix of variables are showed as Table 1. The study uses Cronbach's $\alpha$ to test the reliabilities of the measurements. The dimensions of service quality of physical government are service outcome, environment and interaction services, and the Cronbach's $\alpha$ of three dimensions are $.961, .946$ and .976 . The Cronbach's $\alpha$ of the physical government service quality is .983 . The Cronbach's $\alpha$ of the citizens' satisfaction and citizens' word-of-mouth are .967 and .973 . The Cronbach's $\alpha$ of the e-government service quality are efficiency, trust, reliability and citizen support. The Cronbach's $\alpha$ of the four dimensions are .979, .966, 965 and .951. The Cronbach's $\alpha$ of the e-government service quality is .987 . The Cronbach's $\alpha$ of the citizens' satisfaction and citizens' satisfaction of the e-government are .969 and .964 . All Cronbach's $\alpha$ are higher than .7 and show that the reliabilities for each variable are acceptable and internal consistencies are good. (Nunnally, 1978). The researchers apply confirmatory factor analysis (CFA) method to test the convergent validities of the scales. The results show that all average variance extracted (AVE) and composite reliabilities of the scales are higher than .5 (Fornell and Larcker, 1981). The results show the convergent validities of the all variables are good. The square roots of the average variance extracted (AVE) of each construct are greater than the interconstructs correlations (Table 1), and the results confirm the discriminant validity of the scales (Gaski and Nevin, 1985).

Table 1: Mean, stander deviation, and correlation matrixes
\begin{tabular}{|l|r|r|l|l|l|l|}
\hline Variables & $\begin{array}{l}\text { Service } \\
\text { Quality }\end{array}$ & Satisfaction & $\begin{array}{l}\text { Word-of- } \\
\text { Mouth }\end{array}$ & $\begin{array}{l}\text { e-Service } \\
\text { Quality }\end{array}$ & $\begin{array}{l}\text { e- } \\
\text { Satisfaction }\end{array}$ & $\begin{array}{l}\text { e- Word-of- } \\
\text { Mouth }\end{array}$ \\
\hline 1. Service Quality & $(.954)$ & & & & & \\
\hline 2. Satisfaction & $.808^{* *}$ & $(.953)$ & & & & \\
\hline 3. Word-of-Mouth & $.847^{* *}$ & $.876^{* *}$ & $(.962)$ & & & \\
\hline 4.e-Service Quality & $.815^{* *}$ & $.711^{* *}$ & $.739^{* *}$ & $(.955)$ & & \\
\hline
\end{tabular}


INTERNATIONAL CONFERENCE ON MANAGEMENT , ECONOMICS AND HUMANITIES

\section{6-28 July, 2019 \\ London, United Kingdom}

\begin{tabular}{|l|c|c|c|c|c|c|}
\hline 5. e-Satisfaction & $.801 * *$ & $.745^{* *}$ & $.744 * *$ & $.873^{* *}$ & $(.949)$ & \\
\hline 6. e-Word-of-Mouth & $.780^{* *}$ & $.645^{* *}$ & $.731^{* *}$ & $.815^{* *}$ & $.830^{* *}$ & $(.945)$ \\
\hline Mean & 5.255 & 5.427 & 5.225 & 5.304 & 5.276 & 5.074 \\
\hline S.D. & .975 & 1.161 & 1.128 & .928 & 1.025 & 1.120 \\
\hline
\end{tabular}

Note: $* * p<0.01$, The parentheses numbers in the diagonal row are square roots

of the average variance extracted ( $A V E)$.

The researchers apply regression analysis method to test the hypothesis and the empirical results are showed in the Table 2 and Table 3. In the Table 2, the study tests the relationships among service quality of the physical government, citizens' satisfaction and citizens' word-of-mouth. In the regression model $1 \mathrm{a}$, the researchers test the impact of service quality of the physical government on the citizens' satisfaction. The regression analysis results show that the standardized regression coefficients $\beta=.808$ ( $\mathrm{t}$ value $=18.534, \mathrm{p}<.001^{* * *}$ ) and the adjusted $\mathrm{R}^{2}$ is .651 . The empirical results show that the hypothesis $1 \mathrm{a}(\mathrm{H} 1 \mathrm{a})$ of the study is supported. The results indicate that the higher of citizens perceived service quality of the physical government, the higher of the citizens' satisfaction. The government should improve the physical service quality to improve the citizens' satisfaction. In the regression model $2 \mathrm{a}$, the researchers test the impact of service quality of the physical government on the citizens' word-of-mouth. The regression analysis results show that the standardized regression coefficients $\beta=.847$ ( $\mathrm{t}$ value $=21.574, \mathrm{p}<.001^{* * *}$ ) the adjusted $\mathrm{R}^{2}$ is .716. The empirical results show that the hypothesis $2 \mathrm{a}(\mathrm{H} 2 \mathrm{a})$ of the study is supported. The results indicate that the higher of citizens perceived service quality of the physical government, the higher of the citizens' word-of-mouth. The improving of the government physical service quality will improve the citizens' word-of-mouth intention. The results of regression model 1a and model $2 \mathrm{a}$ show that service quality of the physical government positively impacts on both citizens' satisfaction and word-of-mouth. In the regression model 3a, the researchers test the impact of the citizens' satisfaction on the citizens' word-of-mouth. The regression analysis results show that the standardized regression coefficients $\beta=.876\left(\mathrm{t}\right.$ value $\left.=24.619, \mathrm{p}<.001^{* * *}\right)$ the adjusted $\mathrm{R}^{2}$ is .767 . The empirical results confirm the hypothesis $3 \mathrm{a}(\mathrm{H} 3 \mathrm{a})$ of the study. The results show that the higher of citizens' satisfaction of the physical government, the higher of citizens' word-of-mouth. The government improve the level of citizens' satisfaction would improve citizens' word-of-mouth intentions.

The study follows the process of Baron and Kenny (1986) to test the role of the mediator. The researchers apply the fourth regressions to analysis the mediating role of citizens' satisfaction of the relationship between service quality of physical government and citizens' word-of-mouth. The mediating role exists when the main paths ( $\beta$ coefficient) of service quality of physical government on the citizens' word-of-mouth become non-significant or reduced when the variable of citizens' satisfaction is added to the regression analysis. In the regression model $4 \mathrm{a}$, two independent variables, service quality of physical government and citizens' satisfaction, and the one dependent variable, citizens' word-of-mouth, are analyzed. From the results of model 1a and 3a, the impacts of service quality of physical government on citizens' satisfaction and citizens' word-of-mouth are both significant. Comparing the result of model $4 \mathrm{a}$ with the model 1a, after both citizens' satisfaction and citizens' word-of-mouth entered the regression model $4 \mathrm{a}$, the adjusted $\beta$ 


\section{$9^{\text {th }}$ INTERNATIONAL CONFERENCE ON}

MANAGEMENT , ECONOMICS AND HUMANITIES

\section{6-28 July, 2019 \\ London, United Kingdom}

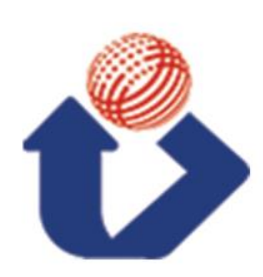

coefficient of service quality of physical government on citizens' word-of-mouth decreased from .808 (model 1a) to .401 (model 4a). The analysis results show that citizens' satisfaction partly mediates the relationship between service quality of physical government and citizens' word-ofmouth. Therefore, the fourth hypothesis of the study (H4a) is partly supported.

Table 2: Regression analysis -physical government services

\begin{tabular}{|l|c|c|c|c|}
\hline Dependent Variables & Satisfaction & \multicolumn{3}{|c|}{ Word-of-Mouth } \\
\hline & Model 1a & Model 2a & Model 3a & Model 4a \\
\hline $\begin{array}{l}\text { Independent } \\
\text { Variables }\end{array}$ & & & & \\
\hline Service Quality & $.808^{* * *}$ & $.847^{* * *}$ & & $.401^{* * *}$ \\
& $(18.534)$ & $(21.574)$ & & $(7.598)$ \\
\hline Satisfaction & & & $.876^{* * *}$ & $.553^{* * *}$ \\
& & & $(24.619)$ & $(10.475)$ \\
\hline Adjusted $\mathrm{R}^{2}$ & .651 & .716 & .767 & .822 \\
\hline Results & Supported & Supported & Supported & Partially supported \\
\hline
\end{tabular}

*** $p<.001$, numbers in parentheses are $t$ value.

In the Table 3, the study tests the relationships among e-government service quality of the physical, citizens' e-satisfaction and e-word-of-mouth. In the regression model $1 \mathrm{~b}$, the researchers test the impact of e-government service quality on the citizens' e-satisfaction. The regression analysis results show that the standardized regression coefficients $\beta=.873(\mathrm{t}$ value $=24.179, \mathrm{p}<$ $.001 * * *)$ and the adjusted $\mathrm{R}^{2}$ is .760 . The empirical results show that the hypothesis $1 \mathrm{~b}(\mathrm{H} 1 \mathrm{~b})$ of the study is supported. The results indicate that the higher of citizens perceived e-government service quality, the higher of the e-citizens' satisfaction. The government should improve the online service quality to increase the citizens' e-satisfaction. In the regression of the model $2 b$, the researchers test the impact of e-government service quality on the citizens' e-word-of-mouth. The regression analysis results show that the standardized regression coefficients $\beta=.815(\mathrm{t}$ value $=19.040, \mathrm{p}<.001^{* * *}$ ) the adjusted $\mathrm{R}^{2}$ is .663 . The empirical results show that the hypothesis $2 \mathrm{~b}(\mathrm{H} 2 \mathrm{~b})$ of the study is supported. The results indicate that the higher of citizens perceived egovernment service quality, the higher of the citizens' e-word-of-mouth. The improving of the government online service quality will increase the citizens' e-word-of-mouth intention. The results of the regression model $1 \mathrm{~b}$ and model $2 \mathrm{~b}$ show that e-government service quality positively impacts on both citizens' e-satisfaction and e-word-of-mouth. In the regression of the model $3 \mathrm{~b}$, the study tests the impact of the e-citizens' satisfaction on the citizens' e-word-of-mouth. The regression analysis results show that the standardized regression coefficients $\beta=.830(\mathrm{t}$ value $=20.158, \mathrm{p}<.001^{* * *}$ ) the adjusted $\mathrm{R}^{2}$ is .688 . The empirical results confirm the hypothesis $3 \mathrm{~b}(\mathrm{H} 3 \mathrm{~b})$ of the study. The results show that the higher of citizens' e-satisfaction of the online government, the higher of citizens' e-word-of-mouth. The government improve the level of citizens' e-satisfaction would improve citizens' e-word-of-mouth intentions. 


\title{
$9^{\text {th }}$ INTERNATIONAL CONFERENCE ON MANAGEMENT , ECONOMICS AND HUMANITIES
}

\author{
26-28 July, 2019 \\ London, United Kingdom
}

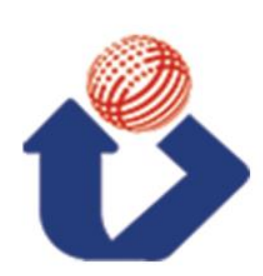

The study applies the fourth regressions to analysis the mediating role of citizens' satisfaction of the relationship between e-government service quality and citizens' e-word-of-mouth. In the regression of model $4 \mathrm{~b}$, two independent variables, e-government service quality and citizens' esatisfaction, and the one dependent variable, citizens' e-word-of-mouth, are analyzed in the regression of model $4 \mathrm{~b}$. The results of the model $1 \mathrm{~b}$ and $3 \mathrm{~b}$ show that the impacts of e-government service quality on citizens' e-satisfaction and e-word-of-mouth are both significant. Comparing the result of the model $4 \mathrm{~b}$ with the model $1 \mathrm{~b}$, after both citizens' e-satisfaction and citizens' eword-of-mouth entered the regression of the model $4 \mathrm{~b}$, the adjusted $\beta$ coefficient of service quality of physical government on citizens' word-of-mouth decreased from .873 (model 1b) to .380(model $4 b)$. The analysis results show that citizens' e-satisfaction partly mediates the relationship between e-government service quality and citizens' e-word-of-mouth. The fourth hypothesis of the study (H4b) is partly supported.

Table 3: Regression analysis - e government services

\begin{tabular}{|c|c|c|c|c|}
\hline \multirow[t]{2}{*}{ Dependent Variables } & \multirow{2}{*}{$\begin{array}{c}\text { e-Satisfaction } \\
\text { Model 1b }\end{array}$} & \multicolumn{3}{|c|}{$\begin{array}{l}\text { e-Word-of- } \\
\text { Mouth }\end{array}$} \\
\hline & & Model 2b & Model 3b & Model 4b \\
\hline \multicolumn{5}{|l|}{ Independent Variables } \\
\hline e-Service Quality & $\begin{array}{l}.873 * * * \\
(24.179)\end{array}$ & $\begin{array}{l}.815^{* * *} \\
(19.040)\end{array}$ & & $\begin{array}{l}.380^{* * *} \\
(4.761)\end{array}$ \\
\hline e-Satisfaction & & & $\begin{array}{l}.830 * * * \\
(20.158) \\
\end{array}$ & $\begin{array}{l}.499 * * * \\
(6.254) \\
\end{array}$ \\
\hline Adjusted $\mathrm{R}^{2}$ & .760 & .663 & .688 & .721 \\
\hline Results & Supported & Supported & Supported & Partially supported \\
\hline
\end{tabular}

Comparing the results between the physical and online government environment (see Table 2 and Table 3), the results are highly similar. The study confirms the relationships between service quality, citizen's satisfaction and citizen word-of-mouth in both physical and online government environments. In the physical government environment, service quality positively impacts on both citizens' satisfaction (standardized $\beta=.808$ and adjusted $\mathrm{R}^{2}=.651$ ) and word-of-mouth (standardized $\beta=.847$ and adjusted $\mathrm{R}^{2}=.716$ ). Besides, the citizens' satisfaction positively impacts on citizens' word-of-mouth (standardized $\beta=.876$ and adjusted $\mathrm{R}^{2}=.767$ ). In the multiple regression of the model $4 \mathrm{a}$ (adjusted $\mathrm{R}^{2}=.822$ ), both service quality (standardized $\beta=.401$ ) and citizens' satisfaction (standardized $\beta=.553$ ) positively impacts on citizens' word-of-mouth. In the online government environment, e-service quality positively also impacts on both citizens' e-satisfaction (standardized $\beta=.873$ and adjusted $\mathrm{R}^{2}=.760$ ) and e-word-of-mouth (standardized $\beta=.813$ and adjusted $\mathrm{R}^{2}=.663$ ). Besides, citizens' e-satisfaction positively impacts on citizens' e-word-ofmouth (standardized $\beta=.830$ and adjusted $\mathrm{R}^{2}=.688$ ). In the multiple regression of the model $4 \mathrm{~b}$ (adjusted $\mathrm{R}^{2}=.721$ ), both e-service quality (standardized $\beta=.380$ ) and citizens' e-satisfaction (standardized $\beta=.499$ ) positively impacts on citizens' e-word-of-mouth. 


\section{Discussions}

\section{Conclusion}

In the age of information technology, public-sectors around the word provide both physical and online services to the citizens. The researchers study both physical and online government services in Taiwan. The researchers study the relationships among service quality, citizen satisfaction and citizen word-of-mouth in the both physical and online environments. The empirical results confirm that: First, the researchers confirm that physical service quality of the government positively impacts on both citizens' satisfaction and word-of-mouth, and citizens' satisfaction positively impacts on citizens' word-of-mouth. The results show that the improving of the physical service qualities, such as stability, failure recovery, hard and soft environment, standardization, easiness, guarantees and customer relations, the governments will increase the level of citizens' satisfaction and word-of-mouth. Similarly, increasing the level of citizens' satisfaction will increase the level of citizens' word-of-mouth. The results of the study confirm the positive relationships between physical service quality of the government, citizens' satisfaction and citizens' word-of-mouth (Rhee and Rha, 2009; Van Ryzin et al., 2004; Wen and Chen, 2007). Besides, the study results confirm that mediating role of the citizens' satisfaction between the government service quality and citizens' word-of-mouth in the physical environments. The results support the results of the previous studies (Ng, David, and Dagger, 2011).

Second, the researchers confirm that e-government service quality positively impacts on both citizens' e-satisfaction and citizens' e-word-of-mouth, and citizens' e-satisfaction positively impacts on citizens' e-word-of-mouth. The results show that the improving of the online websites service, such as efficiency, trust, reliability and citizen support, the governments will increase the citizens' satisfaction and word-of-mouth of the government websites. Then, increasing the citizens' e-satisfaction will increase the level of citizens' e-word-of-mouth. The results also confirm the positive relationships between government online service quality of the, citizens' esatisfaction and citizens' e-word-of-mouth (Bannister and Kearney, 2010; Ha and Lee, 2010; Hu et al., 2009; $\mathrm{Ku}$ and Chen, 2015; Sa, Rocha and Cota, 2016; Verdegem and Verleye, 2009). Besides, the results confirm that mediating role of the citizens' e-satisfaction between the government online service quality and citizens' e-word-of-mouth. The results support the results of the previous studies (Chung, Sheu and Chien, 2007; Teo, Srivastava and Jiang, 2008; Veeramootoo, Nunkoo and Dwivedi, 2018).

Comparing the physical with the online environment, the research results show the similar effects in both government services. The study confirms the positive relationships between service quality, citizens satisfaction and citizen word-of-mouth in both physical and online government environments. The improving of the service quality of the governments will improve the citizens satisfaction and word-of-mouth in both physical and online environments. The governments should improve both physical and online service quality to increase the citizens' positive evaluations and behavioral intentions.

\section{Limitations and Future Research Directions}

There are some research limitations of the study and the researchers provide some suggestions for the future researches. First, the study only explores service quality, citizen satisfaction and 


\section{$9^{\text {th }}$ INTERNATIONAL CONFERENCE ON MANAGEMENT , ECONOMICS AND HUMANITIES}

citizen word-of-mouth in the both physical and online environments. The future researches could study the effects of other variables, such as the impacts of the governments' innovativeness or security. Second, the research samples are the citizens in Taiwan and the study results maybe different in other regions. Future studies could study the different samples in other regions. Third, the researchers study in both physical and online government environments, however, the research samples maybe have different memories or usage experiences between physical and online government environments. Future studies should control the possible different impacts between physical and online environments. Fourth, the study uses cross-sectional method and the study results may be biased. The future studies could use other research methods to collect the samples information, such as interview or longitudinal method.

\section{Acknowledgment}

We thank Minghsin University of Science and Technology for funding the study (MUST-107 SM-2).

\section{References}

Bai, C. H., Lai, F. J., Chen, Y., \& Hutchinson, J. (2008). Conceptualising the perceived service quality of public utility services: A multi-level, multi-dimensional model. Total Quality Management \& Business Excellence, 19(10), 1055-1070. doi:10.1080/14783360802264228

Baron, R. M., \& Kenny, D. A. (1986). The Moderator-Mediator Variable Distinction in Social Psychological Research: Conceptual, Strategic, and Statistical Considerations. Journal of Personality and Social Psychology, 51(6), 1173-1182. doi:10.1037//0022-3514.51.6.1173

Beldad, A., van der Geest, T., de Jong, M., \& Steehouder, M. (2012). A cue or two and I'll trust you: Determinants of trust in government organizations in terms of their processing and usage of citizens' personal information disclosed online. Government Information Quarterly, 29(1), 41-49. doi:10.1016/j.giq.2011.05.003

Chang, C. L.-H., Yu, C.-P., \& Hung, C.-Y. (2010). Assessing Stakeholders Participants as a Means of E-Govern in Taiwan. Journal of Information Management, 17(2), 201-231. 


\section{$9^{\text {th }}$ INTERNATIONAL CONFERENCE ON}

MANAGEMENT , ECONOMICS AND HUMANITIES

Chen, C. K., Yu, C. H., \& Chang, H. C. (2005). An empirical analysis of customer-oriented service activities in the Taiwanese public sector. Total Quality Management \& Business Excellence, 16(7), 887-901. doi:10.1080/14783360500077369

Chung, Y. K., Sheu, L. C., \& Chien, S. H. L. (2007). A model of users' satisfaction with Taiwan's Government website. Psychological Reports, 101(2), 395-406. doi:10.2466/pr0.101.2.395406

Connolly, R., Bannister, F., \& Kearney, A. (2010). Government website service quality: a study of the Irish revenue online service. European Journal of Information Systems, 19(6), 649-667. doi:10.1057/ejis.2010.45

Folz, D. H. (2004). Service quality and benchmarking the performance of municipal services. Public Administration Review, 64(2), 209-220. doi:10.1111/j.1540-6210.2004.00362.x

Fornell, C., \& Larcker, D., F. (1981). Evaluating structural equation models with unobservable variables and measurement error. Journal of Marketing Research, 18(1), 39-50.

Gaski, J. F., \& Nevin, J. R. (1985). The Differential Effects of Exercised and Unexercised Power Sources in a Marketing Channel. Journal of Marketing Research, 22(2), 130-142.

Ha, S. H., \& Lee, M. J. (2010). Customer service quality improvement in the public sector through the Internet. Total Quality Management \& Business Excellence, 21(11), 1161-1176. doi:10.1080/14783363.2010.529341

Hu, P. J. H., Brown, S. A., Thong, J. Y. L., Chan, F. K. Y., \& Tam, K. Y. (2009). Determinants of Service Quality and Continuance Intention of Online Services: The Case of eTax. Journal of the American Society for Information Science and Technology, 60(2), 292-306. doi:10.1002/asi.20956

Janita, M. S., \& Miranda, F. J. (2018). Quality in e-Government services: A proposal of dimensions from the perspective of public sector employees. Telematics and Informatics, 35(2), 457-469. doi:10.1016/j.tele.2018.01.004

Ku, E. C. S., \& Chen, C. D. (2015). Cultivating travellers' revisit intention to e-tourism service: the moderating effect of website interactivity. Behaviour \& Information Technology, 34(5), 465-478. doi:10.1080/0144929x.2014.978376

Liang, S. W., Lu, H. P., \& Kuo, T. K. (2014). A Study on Using the Kano Two-Dimensional Quality Model to Evaluate the Service Quality of Government Websites. Journal of Internet Technology, 15(2), 149-162. doi:10.6138/jit.2014.15.2.01

Mirchandani, D. A., Johnson, J. H., \& Joshi, K. (2008). Perspectives of citizens towards egovernment in Thailand and Indonesia: A multigroup analysis. Information Systems Frontiers, 10(4), 483-497. doi:10.1007/s10796-008-9102-7

Ng, S., David, M. E., \& Dagger, T. S. (2011). Generating positive word-of-mouth in the service experience. Managing Service Quality, 21(2), 133-151. doi:10.1108/09604521111113438

Nunnally, J. C. (1978). Psychometric Theory (2 ed.). New York, NY McGraw-Hill 


\title{
$9^{\text {th }}$ INTERNATIONAL CONFERENCE ON
} MANAGEMENT , ECONOMICS AND HUMANITIES

\author{
26-28 July, 2019
}

London, United Kingdom

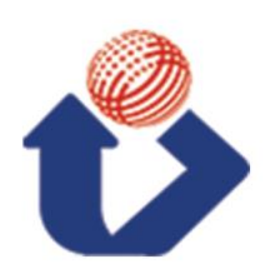

Papadomichelaki, X., \& Mentzas, G. (2012). e-GovQual: A multiple-item scale for assessing egovernment service quality. Government Information Quarterly, 29(1), 98-109. doi:10.1016/j.giq.2011.08.011

Rana, N. P., Dwivedi, Y. K., Williams, M. D., \& Weerakkody, V. (2015). Investigating success of an e-government initiative: Validation of an integrated IS success model. Information Systems Frontiers, 17(1), 127-142. doi:10.1007/s10796-014-9504-7

Rehman, M., Kamal, M. M., \& Esichaikul, V. (2016). Adoption of e-Government Services in Pakistan: A Comparative Study Between Online and Offline Users. Information Systems Management, 33(3), 248-267. doi:10.1080/10580530.2016.1188570

Rhee, S. K., \& Rha, J. Y. (2009). Public service quality and customer satisfaction: exploring the attributes of service quality in the public sector. Service Industries Journal, 29(11), 1491-1512. doi:10.1080/02642060902793441

Sa, F., Rocha, A., \& Cota, M. P. (2016). From the quality of traditional services to the quality of local e-Government online services: A literature review. Government Information Quarterly, 33(1), 149-160. doi:10.1016/j.giq.2015.07.004

Schedler, K., \& Summermatter, L. (2007). Customer orientation in electronic government: Motives and effects. Government Information Quarterly, 24(2), 291-311. doi:10.1016/j.giq.2006.05.005

Stock, R. M. (2011). How does product program innovativeness affect customer satisfaction? A comparison of goods and services. Journal of the Academy of Marketing Science, 39(6), 813827. doi:10.1007/s11747-010-0215-4

Teo, T. S. H., Srivastava, S. C., \& Jiang, L. (2008). Trust and Electronic Government Success: An Empirical Study. Journal of Management Information Systems, 25(3), 99-131. doi:10.2753/mis0742-1222250303

Van Ryzin, G. G., Muzzio, D., Immerwahr, S., Gulick, L., \& Martinez, E. (2004). Drivers and consequences of citizen satisfaction: An application of the American Customer Satisfaction Index Model to New York City. Public Administration Review, 64(3), 331-341.

Veeramootoo, N., Nunkoo, R., \& Dwivedi, Y. K. (2018). What determines success of an egovernment service? Validation of an integrative model of e-filing continuance usage. Government Information Quarterly, 35(2), 161-174. doi:10.1016/j.giq.2018.03.004

Venkatesh, V., Thong, J. Y. L., Chan, F. K. Y., \& Hu, P. J. H. (2016). Managing Citizens' Uncertainty in E-Government Services: The Mediating and Moderating Roles of Transparency and Trust. Information Systems Research, 27(1), 87-111. doi:10.1287/isre.2015.0612

Verdegem, P., \& Verleye, G. (2009). User-centered E-Government in practice: A comprehensive model for measuring user satisfaction. Government Information Quarterly, 26(3), 487-497. doi:10.1016/j.giq.2009.03.005 
Wen, Y.-F., \& Chen, C.-H. (2007). A Study on the Factors of Service Quality of Local Administrative Organizations: An Example of Tainan City Government. Journal of Quality, 14(2), 149-159.

Wisniewski, M., \& Donnelly, M. (1996). Measuring service quality in the public sector: The potential for SERVQUAL. Total Quality Management, 7(4), 357-365. 